\title{
Leksyka słowiańskich dialektów miejskich: egzoetnonimy w gwarze Warszawy, Brna i Moskwy
}

\author{
The vocabulary of Slavonic urban dialects: \\ Exoethnonyms in Warsaw, Brno and Moscow dialects
}

\begin{abstract}
The present study concentrates on the issue of exoethnonyms and, in particular, exoethnonyms replacing orthonyms in the vocabulary of Slavonic urban dialects - namely, the urban dialect of Warsaw, the Hantec slang of Brno and the urban dialect of Moscow. Based on the data extracted from dictionaries, it was possible to select such designations. From the linguistic point of view, these nominations are either occasionalisms or names more deeply rooted in the lexical system of the urban dialects in question. The article includes the analysis and classification of the research data in terms of the linguistic and extralinguistic motivation and axiological evaluation of particular items.
\end{abstract}

Keywords: ethnonyms, abusive exoethnonym, Warsaw urban dialect, Hantec slang of Brno, Moscow urban dialect

Bartosz Juszczak, Uniwersytet Wrocławski, Wrocław - Polska, bartosz.juszczak@uwr.edu.pl, ORCID ID: https://orcid.org/0000-0002-7058-0384

Dialekty miejskie są formacjami interesującymi pod wieloma względami, gdyż stanowią przykłady potocznych wariantów języka narodowego, które ukształtowały się na przełomie XIX i XX wieku, w okresie dużych przemian społecznych i gospodarczych w całej Europie. W swoich strukturach zawierają elementy języka potocznego, codziennego. Ważną rolę odgrywa w nich swoista leksyka, która poprzez struktury i motywacje oddaje koloryt minionych czasów, wskazuje na stosunki międzyludzkie i kreuje obraz użytkowników tych kodów językowych.

Badanie dialektów miejskich (dalej DM) w perspektywie diachronicznej jest ważne z co najmniej kilku powodów. Po pierwsze, nie zostały one do dziś poddane wszechstronnej analizie językoznawczej, przede wszystkim w zakresie ich semantyki i motywacji w wymiarze całościowym; po drugie, badanie tych formacji z uwzględnieniem nowych metodologii, zwłaszcza aspektów językowo-kultu- 
rowych (zob. np. Święcicka 2006, 2012), które w dzisiejszych czasach zyskują na popularności wśród lingwistów słowiańskich, pozwala na rekonstrukcję językowego obrazu ówczesnych miast i ich mieszkańców, wskazuje na zainteresowania, profesje oraz cechy charakteru mieszkańców, a także stosunki z sąsiadami i ich jakość. Badania te są istotne, gdyż pozwalają porównać utrwalone w świadomości narodu różnego rodzaju stereotypy socjalne $\mathrm{z}$ faktami językowymi, dzięki którym jesteśmy w stanie zrekonstruować stereotyp językowy miast i ich mieszkańców.

Leksyka interesujących mnie $\mathrm{DM}^{1}$ jest bardzo zróżnicowana, a jej pogrupowanie w pola semantyczne pokazuje całkowitą funkcjonalność komunikatywną tych kodów językowych na płaszczyźnie potocznych, codziennych kontaktów mieszkańców badanych miast. Poszczególne DM mają pokrywającą się liczbę grup tematycznych leksyki, różną natomiast w zakresie wypełnienia ilościowego danej grupy. Jest to m.in. konsekwencją indywidualnego podejścia leksykografa w selekcji szerokiego materiału językowego, gdyż nie wszystkie jednostki zostają uwzględnione w opracowaniu końcowym. We wszystkich trzech formacjach miejskich wyróżnić można pokrywające się zakresy tematyczne: 1. Człowiek jako istota psychiczna; 2. Człowiek jako istota fizyczna²; 3. Używki; 4. Prostytucja; 5. Zawody; 6. Elementy przestrzeni miejskiej; 7. Transport miejski; 8. Handel i usługi; 9. Narodowości. We wszystkich DM zawartość materiałowa (językowa) tych pól jest podobna lub całkowicie pokrywa się, co wskazuje z jednej strony na dużą zbieżność, lecz również i na indywidualność językowo-kulturową miasta i jego mieszkańców.

W niniejszym artykule zostanie zaprezentowana i przeanalizowana grupa egzoetnonimów i etnonimów przezwiskowych ${ }^{3}$ narodowości rejestrowanych w trzech słowiańskich DM - gwarze warszawskiej (dalej GW), brneńskim hantecu (dalej H) i dialekcie miejskim Moskwy (dalej DMM) w aspekcie semantycznym i pragmatycznym, a także pod kątem ewentualnego udziału tych jednostek leksykalnych w budowaniu stereotypów etnicznych określonych narodów ${ }^{4}$. Zebrany materiał zostanie przeanalizowany z perspektywy motywacji poszczególnych nazw (motywacja językowa i pozajęzykowa), a także ich oceny aksjologicznej.

\footnotetext{
1 W kręgu moich zainteresowań znajdują się DM Warszawy, Brna, Moskwy, a ponadto Lwowa i Poznania w aspekcie językowo-kulturowego obrazu przestrzeni miejskiej.

${ }^{2}$ Nazw dwóch pierwszych grup tematycznych używam za Małgorzatą Witaszek-Samborską i Anną Piotrowicz.

${ }^{3}$ Etnonimy przezwiskowe budowane są na zasadzie charakterystycznych cech ludzi stanowiących wspólnotę (Cieślikowa 181).

${ }^{4}$ Przez pojęcie stereotypu rozumiem za Jerzym Bartmińskim ,subiektywnie determinowane wyobrażenie przedmiotu obejmujące zarówno cechy opisowe, jak i wartościujące oraz będące rezultatem interpretacji rzeczywistości w ramach społecznych modeli poznawczych" (Bartmiński 64).
} 
Materiał językowy niezbędny do zrealizowania tak sformułowanych zadań badawczych został wyekscerpowany z trzech źródeł leksykograficznych, które kodyfikują leksykę dialektów miejskich badanych miast ${ }^{5}$. Warto dodać, że tego typu nominacje pojawiają się również w innych źródłach opisujących historię danego miasta (źródła pamiętnikarskie, historyczne, biograficzne i in. ${ }^{6}$ ).

Pierwsze z nich to Stownik gwary warszawskiej XIX wieku (Wieczorkiewicz). Źródło to zawiera ok. 9 tys. leksemów, zróżnicowanych pod względem używalności przez poszczególne grupy społeczne zamieszkujące Warszawę (rzemieślnicy, mieszczanie, studenci, półświatek przestępczy). Słownik Bronisława Wieczorkiewicza to autentyczny zapis języka mieszkańców XIX-wiecznej Warszawy, których gwara miejska powstała na podłożu gwar północno-mazowieckich i znalazła się pod wpływem oddziaływań języków i kultur obcych, przede wszystkim języka rosyjskiego (w największym stopniu), a także języka niemieckiego i jidysz. Śladem tych relacji są pozostałości językowe w postaci zapożyczeń oraz kalk semantycznych i strukturalnych.

Brneński hantec, podobnie jak GW, ukształtował się na przełomie XIX i XX wieku. Rozwój tej formacji jest jednak nieco odmienny. Powstał również na podłożu gwar terytorialnych (gwary hanackie), jednakże oddziaływanie języka obcego, niemieckiego, na jego struktury miało inną jakość ze względu na bilingwizm czesko-niemiecki i neutralne kontakty społeczne koegzystujących ze sobą narodów w Brnie i jego bliskich granicach. Materiał odnoszący się do H został wyekscerpowany ze słownika czeskiego języka nieliterackiego (Hugo), który oddaje leksykę H całościowo, a nie tylko i wyłącznie przez pryzmat socjolektu grupy społecznej Plotny, jak w słowniczku Otakara Nováčka (Nováček).

Dialekt miejski Moskwy (ros. обиходно-разговорный язык Москвы) to formacja o parametrach lingwistycznych zbliżonych do wcześniej wspomnianych dialektów miejskich Warszawy i Brna. Istniejące podobieństwa można zaobserwować na płaszczyźnie chronologicznej, socjalnej, funkcjonalno-komunikatywnej, strukturalnej oraz pragmatycznej. Stoję na stanowisku, że DMM może być zestawiony z GW i H. Badana formacja językowa doczekała się również opracowania leksykograficznego, nieco innego charakteru niż wcześniejsze słowniki, gdyż dodatkowo poza materiałem językowym zawiera szerokie komentarze omawianych jednostek, odnoszących się do kultury i codziennego życia XIX-wiecznej Moskwy. Ujęty w nim materiał to leksyka zaczerpnięta z prac o Moskwie, powstałych w XIX i XX wieku, a także literatury pięknej „moskiewskiej”. Słow-

${ }^{5}$ Wziąłem pod uwagę tylko i wyłącznie opracowania sensu stricto leksykograficzne. W zakresie leksyki DM powstają również opracowania amatorskie, w wersjach papierowych i internetowych.

${ }^{6} \mathrm{Na}$ bazie tego typu tekstów powstał m.in. słownik Władimira Jelistratowa. 
nik Władimira Jelistratowa Âzyk staroj Moskvy. Lingvoènciklopedičeskij slovar' (Elistratov) zawiera ok. 4 tys. zróżnicowanych pod względem semantyki haseł.

Badania etnonimów w literaturze onomastycznej mają dość długą historię we wszystkich interesujących nas językach narodowych, choć stopień opracowania tego zagadnienia jest różny ${ }^{7}$. Etnonimy nazywają ,grupy wspólnotowe, które łączą więzi społeczne, kulturowe, język, a także wspólnie zajmowany teren" (Rzetelska-Feleszko et al. 479). Z punktu widzenia klasyfikacji wyróżnić możemy dwa rodzaje tego typu nominacji: (1) nazwy wychodzące od danej grupy (endogeniczne), np. Słowianie oraz (2) powstałe na zasadzie opozycji swój vs. obcy, tj. Niemcy, Rosjanie itd. (Rzetelska-Feleszko et al. 479). W przypadku tych drugich, opierających się na opozycji, mamy do czynienia najczęściej z nominacjami obcej proweniencji, które zostały zaadaptowane do polszczyzny, lub nazwami egzogenicznymi (Malec 185). Ciekawy przykład nazw etnonimicznych stanowią egzoetnonimy, czyli nazwy nadane danej społeczności przez przedstawicieli innej grupy społecznej (nazwy zewnętrzne). To właśnie w ich strukturze dostrzec możemy (poza budową językową) różnego rodzaju sądy i oceny, kreujące część stereotypu narodowego. Za nazwy wchodzące w skład egzoetnonimów egzogenicznych możemy uznać również egzoetnonimy przezwiskowe. Nazwy przezwiskowe, jak pisze Aleksandra Cieślikowa, to „emocjonalnie nacechowane, występujące w mikrowspólnocie, czyli są charakterystyczne dla kontaktu nieoficjalnego" (Cieślikowa 121). Takimi właściwościami cechują się DM, będące kodami typowymi dla małej, zamkniętej terytorialnie wspólnoty, funkcjonalnie wykorzystywanymi w kontaktach nieoficjalnych. Nawiązując do zagadnienia stereotypów narodowych, warto zaznaczyć, że nazwy egzoetnonimiczne wiernie i dość bezpośrednio oddają sposób postrzegania członków różnych grup etnicznych, gdyż stanowią element budulcowy ogólnego stereotypu, który jest „determinowany ogólnokulturową opozycją swój-obcy, a także związany z aktualnymi stosunkami i konfliktami pomiędzy tymi grupami” (Bartmiński, Panasiuk 387). W zebranym materiale językowym w zakresie egzoetnonimów istnieje duża dysproporcja z punktu widzenia zróżnicowania geograficznego tych nazw, jak i ich liczby. GW rejestruje 57 jednostek, $\mathrm{H}$ - 10, najmniej jednostek odnajdujemy w DMM - tylko 7 nominacji.

W GW egzoetnonimy podzielić można na dwie grupy. Pierwszą grupę stanowią określenia przedstawicieli narodów, z którymi warszawiacy nie mieli bliższych kontaktów językowo-kulturowych. Wyróżnić możemy: Amerykanin Amerykańczyk, Yankes; Anglik - Anglikanin, Janglik; Belg - Belgik; Francuz Frajcuz; Szwajcar - Gryzoń; Włoch - Italiano; Japończyk - Japoniec; Austriak

${ }^{7} \mathrm{O}$ szerokim opracowaniu tego zagadnienia na gruncie języków słowiańskich świadczą choćby poszczególne rozdziały odnoszące się do wszystkich języków słowiańskich w encyklopedii słowiańskiej onomastyki (Rzetelska-Feleszko et al. 476-535). 
- Kaiserlik; Litwin - Litwos; Monakijczyk - Monakista; Holender-Olender. Nazwy te to przede wszystkim urobienia polegające m.in. na zniekształceniu nazw państw, np. Amerykańczyk, Anglikanin, Belgik, Japoniec, Litwos. Dwa egzoetnonimy w tej grupie to nominacje obcej proweniencji: Keiserlik (od niem. der Kaiser 'cesarz' lub kaiserlich 'cesarski'); Italiano (wł. Italiano 'włoski', adj.).

Grupa druga to egzoetnonimy nominujące przedstawicieli narodów, z którymi warszawiacy mieli bliższe kontakty. Grupa ta jest liczniejsza. Wyróżnia się również ze względu na motywację i aksjologię poszczególnych określeń. Odnotowujemy tu określenia Niemca: Derdidas, Miemiec, Niemiaszek, Niemra, Pluder, Pludrak, Szkop; Rosjanina: Istinny, Kacap, Ruski oraz w największej ilości Żyda: Beduin, Garbatonosa, Gudtaj, Gudtajka, Izraelita, Jerozolimska Szlachta, Jewrej, Judek, Kaktus, Litwak, Lud wybrany, Łapserdaczka, Łapserdak, Lódzki szlachcic, Mojżesz, Nasz, Niechrzczony, Palestyńczyk, Parch, Persak, Przechrzcianka, Siabsiumćwinik, Starozakonny, Syn Izraela, Szajgec, Szeine morenie, Szwargociarz, Żyd, Żydówica, Żydziak, Żydzisko, Żydziuk.

Egzoetnonimy w H, jak już zostało zasygnalizowane, stanowią mniej liczny zbiór. Również ten materiał rozdzielić można na dwie grupy, podobnie jak w przypadku GW. W skład grupy pierwszej wchodzą zatem jedynie trzy określenia: Włoch - Taloš (urobienie od starej ekspresywnej formy rzecz. Talián 'Włoch'); Węgier, Węgrzy - Feferóni, Paprikáš (od nazw papryki i węgierskiego dania). Grupa druga zawiera nominacje Rosjan - Azbuci (od nazwy alfabetu ros. азбука), Rusál (pogard.); Romów - Morák (od rom. zwrotu more 'przyjacielu, kolego'); Polaków - Pšonci, P̌sonka (od świszczącego dla Czechów odbioru naszej mowy lub od polskiego związku wyr. psiakrew) oraz Czechów - Cajzl, Č́žek (od niem. Das Zeisig 'czyżyk'). Określenia Czechów wprowadzamy tu celowo, co wynika, z wciąż żywego w świadomości Czechów podziału krain geograficznych w Republice Czeskiej: Czechy właściwe, Morawy i Śląsk. Mieszkańcy tych regionów wykazują się pewnym indywidualizmem i stronią od generalizacyjnego określenia ich mianem Czechów.

W przyjętym wcześniej podziale materiału językowego egzoetnonimy DMM dzielą się następująco: w skład grupy pierwszej wchodzą określenia Włochów - тальяниы; Niemców - якала, якала шут немецкий 'ironicznie о Niemcu'; тундер-ветер 'ironiczna nazwa Niemca' (od niem. das Donnerwetter 'burza; psia kość!’). Egzoetnonimy grupy drugiej to określenia Chińczyka - кumaёза; Francuzki - франиузенки 'pogardliwie o Francuzce' oraz Żyda - иерусалимский дворянин.

W zaprezentowanym materiale zwraca uwagę duża dysproporcja występowania badanych nazw w różnych dialektach. Odnosi się ona nie tylko do określeń poszczególnych narodów, lecz również do liczby nazw przedstawicieli konkretnej grupy etnicznej. Najbardziej rzuca się w oczy brak jakichkolwiek potocznych 
określeń Niemca w gwarze miejskiej Brna, a wiadomo przecież, że w mieście tym Niemcy byli obecni już od XIII wieku . Fakt ten może być sygnałem i dowodem neutralnych kontaktów obu narodów, których stosunki zmieniły się dopiero po II wojnie światowej. Równie zaskakujący jest brak określeń Polaków w DMM, choć w języku literackim i potocznym tego typu nazwy występują (np.: пиек, пшеки).

Bezsprzecznie najokazalej wygląda kompleks egzoetnonimów pochodzących z gwary warszawskiej, gdzie odnotowujemy nie tylko największą liczbę określeń innych narodów, lecz również, co szczególnie ważne, ,paralelizm nazewniczy” kilku ważnych grup etnicznych: Niemców, Rosjan i szczególnie Żydów. Paralelizm ten zachodzi nie tylko w obrębie jednego DM, ale także obserwujemy go w konfrontacji dwóch gwar, np. Jerozolimska Szlachta i moskiewskie иерусалимский дворянин. Możliwe, że mamy do czynienia z kalką lub importacją z języka rosyjskiego do polskiego. $\mathrm{W}$ dalszych rozważaniach skupię się przede wszystkim na analizie danych dialektu miejskiego Warszawy, a w szczególności określeń Żyda, ponieważ są one najliczniejsze i najciekawsze z punktu widzenia motywacji językowej i pozajęzykowej'.

Wyekscerpowane hasła słownikowe nie są jednorodne z punktu widzenia ich charakteru lingwistycznego i tym samym komunikacyjnego, a także wartości kognitywnej. „Zespół warszawski” stanowią: (1) okazjonalne (ale neutralne) nominacje i (2) deskrypcje oraz (3) określenia wartościujące.

(1) Nominacje okazjonalne (również i w zespołach przykładów z dialektów Brna i Moskwy) odnoszą się przede wszystkim do przedstawicieli narodów, z którymi społeczności miast nie miały do czynienia w kontaktach codziennych. Wyróżnić tu możemy np. warszawskie: Amerykańczyk, Yankes, Anglikanin, Janglik, Belgik, Frajcuz, Gryzoń; brneńskie: Taloš, Feferóni, Paprikáš czy moskiewskie: тальянщзы, франиузенки.

(2) Deskrypcje typu: Garbatonosa, Lud wybrany, Syn Izraela, Niechrzczony, Siabsiumćwinik, Starozakonny, Łódzki szlachcic, Jerozolimska Szlachta (por. moskiewskie: иерусалимский дворянин), Beduin, Kaktus. Jednostki tej grupy mogły pełnić funkcję zarówno neutralnego, jak i wartościującego opisu. Wyrażenia mogły mieć wydźwięk eufemistyczny (Starozakonny, Izraelita, Mojżesz, Syn Izraela), lecz w pragmatyce użycia większości dominuje ironia i sygnał dystansu. Wartościujące deskrypcje nawiązują

${ }^{8}$ O bilingwizmie czesko-niemieckim pisze Marie Krčmová: „stálé soužití obou národností vedlo kdysi k vytváření konverzačního jazyka, který był kombinací lexikálních prvků německých s českým gramatickým systémem” (Krčmová 24).

9 Na temat stereotypów etnicznych, w tym stereotypu etnicznego Żyda, zarówno językowego, jak i społecznego, istnieje bogata literatura naukowa we wszystkich uwzględnionych w artykule językach narodowych. Por. m.in. prace Moniki Łaszkiewicz, Marzeny Marczewskiej, Marka Nekuli oraz Olgi Biełowej i Kiry Łapszynowej. 
do wyglądu zewnętrznego i stroju: Łapserdak, Łapserdaczka, Gudłaj, Gudtajka lub też potocznego (naiwnego) odbioru dźwięku obcej mowy: Szwargociarz. W ostatnim przykładzie ocena zbudowana jest na semantyce oraz pragmatyce czasownika szwargotać, pot. 'mówić w języku, którego ktoś nie zna lub nie lubi, zwłaszcza po niemiecku' ${ }^{10}$.

(3) Określenia wartościujące stanowią najciekawszą część badanego słownictwa, gdyż to właśnie one w sposób najbardziej bezpośredni oddają charakter relacji między przedstawicielami różnych narodów i narodowości tworzących społeczność miasta: Gudtaj, Gudłajka 'pogardliwie Żyd', Lapserdak, Łapserdaczka 'przestarzałe, pogardliwie o Żydzie'"11, Parch 'przestarzałe, obraźliwie o Żydzie', Szajgec 'pogardliwie młody Żyd'.

Wśród warszawskich egzoetnonimów odnoszących się do Żydów sporą grupę stanowią derywaty fundowane przez różnorodne określenia przedstawicieli tej narodowości i urabiane za pomocą przyrostków (feminatywnych oraz deminutywnych i augmentatywnych): Judek, Persak, Żydówica, Żydziak, Żydzisko, Żydziuk.

Kontynuując próby odtworzenia motywacji poszczególnych określeń Żyda i sytuacji, jakie przyczyniły się do ich powstania, należy przyjrzeć się sposobowi, w jaki nowo nadane określenie łączy się z pierwotnym desygnatem. Pomocą w odtworzeniu stanu rzeczy może być klasyfikacja Czesława Kosyla, który wyróżnia dwa sposoby motywacji przezwisk, a ponadto słownik etymologiczny Aleksandra Brücknera. Pierwszy ze sposobów podanych przez Kosyla to bezpośredni, w którym wyraz motywujący jest użyty w swoim podstawowym znaczeniu, oraz drugi, gdzie wyraz motywujący nazwę użyty jest metaforycznie lub metonimicznie (Kosyl 443). Wśród motywacji bezpośrednich możemy wyróżnić:

a) nazwy zawierające charakterystykę cech zewnętrznych osoby nazywanej (wygląd zewnętrzny, wiek, styl ubioru): Garbatonosa, Gudłaj, Gudłajka (od ukr. Кудлай 'człowiek z rozczochranymi włosami'), Łapserdaczka, Łapserdak, Parch, Żydzisko, Żydziuk, Żydówica, Żydziak;

b) nazwy zawierające charakterystykę cech wewnętrznych: brak motywacji tego typu;

c) nazwy ze względu na charakterystyczną czynność, sposób wykonywania czynności, mówienia: Szwargociarz;

d) nazwy określające nosiciela ze względu na miejsce pochodzenia lub zamieszkania: Beduin, Jewrej, Judek, Litwak, Persak, Łódzki szlachcic, Żyd.

Drugi zbiór tworzą nazwy pośrednie typu:

${ }^{10} \mathrm{~W}$ GW istnieją również inne czasowniki określające sposób mówienia typowy dla Żydów: tsykanie 'sposób mówienia Żydów żargonem' oraz żargonować - 'mówić w języku jidysz'. Nie tworzą one jednak derywatów egzoetnonimicznych.

${ }^{11}$ Formacje Łapserdak, Łapserdaczka używane były również w szerszych znaczeniach 'człowiek nędznie ubrany' oraz 'nicpoń, łobuz'. 
a) określenia nosiciela motywowane faktami religijnymi na zasadzie metaforyzacji/metonimizacji: Mojżesz, Niechrzczony, Przechrzcianka, Starozakonny;

b) określenia, które są przykładem eufemizmów frazeologicznych (biblijnych): Syn Izraela, Izraelita, Lud wybrany, Palestyńczyk, Jerozolimska Szlachta.

W zgromadzonym materiale językowym wyróżnić można dodatkowo leksemy o niejasnej motywacji pozajęzykowej, np.: Kaktus, Nasz, oraz te bazujące na naśladownictwie języka jidysz bądź wyrażeń w tym języku: Siabsiumćwinik 'postępowy Żyd', Szajgec 'Żyd elegant'.

Interesujące jest, że w materiale językowym GW brakuje określeń Żyda motywowanych cechami wewnętrznymi, cechami charakteru czy usposobienia, choć w języku ogólnym określenia takie istnieją. Pokazał to w swoich badaniach Jerzy Bartmiński, wskazując, że nazwy Żyda, a co za tym idzie, kreowany przez nie stereotyp językowy, mają charakter dychotomiczny, który przejawia się w ujemnych (np. brudny, nieuczciwy w handlu) i dodatnich (np. inteligentny, mądry, skrupulatny) konotacjach (Bartmiński, Panasiuk 388-389). Podobny obraz Żyda wyłonił się z analiz Jarosława Pacuły (Pacuła 142). Przykładem określeń o motywacji wewnętrznej w materiale polsko- i rosyjskojęzycznym są następujące leksemy i związki wyrazowe, np.: żydzić 'być skąpym', жидиться czy związki frazeologiczne: Kochajmy sięjak bracia, liczmy się jak Żydzi; Живи, что брат, а торгуйся, как жид; Родом дворянин, а делами жидовин itp. Struktura leksemów Parch, Jewrej może sugerować, iż w tym przypadku mamy do czynienia z rosyjskimi pożyczkami językowymi.

Analizując leksykę egzoetnonimiczną badanego typu, warto zastanowić się nad jej potencjałem dyskursywnym. Mam tutaj na myśli modusy, w jakich wyrazy te były używane. W niniejszym przypadku można wydzielić dwa: opisowy i bezpośredni. Modus opisowy realizowany był w formule z przyimkiem $\boldsymbol{o}$, np. „o $X / Y \ldots$..., zaś modus bezpośredni w formule bez przyimka: „ty $X / Y$ !”. Modus opisowy „o Żydzie” realizują następujące jednostki: Beduin, Jewrej, Judek, Litwak, Persak, Łódzki szlachcic, Mojżesz, Niechrzczony, Przechrzcianka, Starozakonny, Syn Izraela, Izraelita, Lud wybrany, Palestyńczyk, Jerozolimska Szlachta. Modus bezpośredni to egzoetnonimy kierowane do Żyda w trakcie sytuacji komunikacyjnych, np.: Garbatonosa, Gudtaj, Gudtajka, Łapserdaczka, Łapserdak, Parch, Żydzisko, Żydziuk, Żydówica, Żydziak, Szwargociarz, Żyd. Należy tutaj dodać, iż zwroty bezpośrednie charakteryzują się silną ekspresją, a określenia tu zawarte to przede wszystkim przykłady nominacji przezwiskowych, motywowane w sposób bezpośredni, czyli mające bezpośredni związek z desygnatem ${ }^{12}$.

12 Typologia powyższych modusów jest oparta na zastosowanym schemacie definicyjnym w słowniku GW. 
Określenia pozostałych bliskich sąsiadów użytkowników GW charakteryzują się podobną motywacją językową i pozajęzykową. Motywacje bezpośrednie realizowane są przez jednostki: Pluder, Pludrak (ze względu na ubiór, z niem. Pluderhose 'pludry, rodzaj spodni'), Kacap (wygląd, a także importacja językowa); Derdidas, Miemiec, Niemiaszek, Niemra (sposób mówienia - nawiązanie do niemieckich zaimków oraz utarte określenie Niemca jako osoby niemej); Istinny, Ruski (ze względu na pochodzenie; dodatkowo importacja językowa).

Należy podkreślić, że motywacja określeń Żyda w GW jest warunkowana czynnikami kulturowymi, historycznymi i religijnymi. Większość określeń to jednostki o charakterze przezwiskowym, ekspresywnym i obelżywym. Z punktu widzenia motywacji językowej nazwy te są oparte na różnych procesach derywacyjnych. Ich motywacja pozajęzykowa opiera się przede wszystkim na stereotypowych cechach fizycznych Żyda (ubiór, wygląd, sposób mówienia). Większość z nich, jak to sygnalizowano, ma konotacje ujemne i można je traktować jako przykłady nominacji implikujących agresję werbalną, gdzie, jak pisała Maria Peisert:

Zastąpienie imienia lub nazwiska oponenta leksyką obraźliwą [...], która swoją znieważającą moc czerpie z obniżającego statusu porównania do przedmiotów, zwierząt, itp. [...] budzą ośmieszające, zdeformowane asocjacje z osobą, do której się odnoszą. A ich najważniejszą funkcją jest zepchnięcie oponenta na niższe poziomy hierarchii społecznej (Peisert 156).

Warto zauważyć, że tylko w przypadku określeń Żyda odnajdujemy jednostki odsyłające do jego religijności, w odniesieniu do innych narodowości w badanych DM zjawisko takie nie występuje.

Omawiana leksyka charakteryzuje się różnorodną i bogatą semantyką, a także motywacją językową i pozajęzykową oraz charakterem komunikacyjnym. Z tego też względu niektóre z przytoczonych jednostek mogą być klasyfikowane w różny sposób, gdyż w mojej ocenie realizują dwa różne parametry przyjętej klasyfikacji, np. Gudłaj, Gudtajka jako deskrypcja oraz określenie wartościujące. Przeanalizowany materiał nie odsyła w sposób bezpośredni do stereotypu narodowego poszczególnych nacji. Jednakże w zróżnicowanych kontekstach sytuacyjnych i tekstowych może stanowić ważny nośnik stereotypowych sądów i ocen.

\section{Bibliografia}

Bartmiński, Jerzy. „Podstawy lingwistycznych badań nad stereotypem - na przykładzie stereotypu «matki»". Język a kultura. Stereotyp jako przedmiot lingwistyki: teoria, metodologia, analizy empiryczne. Red. Janusz Anusiewicz, Jerzy Bartmiński, nr 13, 1998, s. 63-83.

Bartmiński, Jerzy, Jolanta Panasiuk. „Stereotypy językowe”. Wspótczesny język polski, V. Red. Jerzy Bartmiński. Wydawnictwo Uniwersytetu Marii Curie-Skłodowskiej, 2014, s. 371-95.

Belova, Ol'ga, Kira Lapšinova. „Osobennosti kognitivnogo i affektivnogo urovnej ètničeskih stereotipov v sovremennom sociume”. Social'naâ politika i sociologiâ, nr 8, 2011, s. 181-93. 
Brückner, Aleksander. Słownik etymologiczny języka polskiego. Warszawa, Wiedza Powszechna, 1970.

Cieślikowa, Aleksandra. „Przezwiska”. Polskie nazwy własne. Encyklopedia. Red. Ewa Rzetelska-Feleszko. Warszawa-Kraków, Wydawnictwo Instytutu Języka Polskiego PAN, 2005, s. 119-34.

Elistratov, Vladimir. Ázyk staroj Moskvy. Lingvoènciklopedičeskij slovar'. Moskva, Russkie slovari, 1997.

Hugo, Jan, red. Slovník nespisovné češtiny. Praha, Maxdorf s.r.o., 2009.

Kosyl, Czesław. „Nazwy osobowe. Przezwiska”. Wspótczesny język polski, V. Red. Jerzy Bartmiński. Lublin, Wydawnictwo Uniwersytetu Marii Curie-Skłodowskiej, 2014, s. 431-445.

Krčmová, Marie. Běžně mluvený jazyk v Brně. Brno, Univerzita J.E. Purkyně, 1981.

Łaszkiewicz, Monika. „Stereotyp Żyda utrwalony w języku polskim”. Stereotypy - walka z wiatrakami? Red. Anna Bujnowska, Joanna Szadura. Lublin, Wydawnictwo Uniwersytetu Marii Curie-Skłodowskiej, 2011, s. 93-102.

Malec, Maria. „Etnonimy. Nazwy narodowości. Nazwy mieszkańców”. Polskie nazwy własne. Encyklopedia. Red. Ewa Rzetelska-Feleszko. Warszawa-Kraków, Wydawnictwo Instytutu Języka Polskiego PAN, 2005, s. 181-87.

Marczewska, Marzena. „Stereotypy etniczne we współczesnym polskim dyskursie publicznym”. Res Historica, nr 46, 2018, s. 283-300.

Nekula, Marek. „Etnické stereotypy a jejich artikulace v češtině (a v němčině)”. Sbornik praci Filozoficke fakulty Brněnské univerzity, t. A47, 1999, s. 65-75.

Nováček, Otakar. Brněnská plotna. Brno, Edice ON svazek I., 1929.

Pacuła, Jarosław. „Polskie i rosyjskie egzoetnonimy i przezwiska Żyda w kontekście stereotypu językowego". Linguarum Silva, nr 1, 2012, s. 135-148.

Peisert, Maria. Formy i funkcje agresji werbalnej. Próba typologii. Wrocław, Wydawnictwo Uniwersytetu Wrocławskiego, 2004.

Rzetelska-Feleszko, Ewa et al. Słowiańska onomastyka: encyklopedia. T. I. Warszawa-Kraków, Towarzystwo Naukowe Warszawskie, 2002.

Święcicka, Małgorzata. „Stereotyp w lingwistycznych badaniach przestrzeni miejskiej: stan, metody, perspektywy”. Języki słowiańskie w ujęciu socjolingwistycznym: prace przygotowane na XV Międzynarodowy Kongres Slawistów Mińsk 2013. Red. Halina Kurek. Kraków, Księgarnia Akademicka, 2012, s. 243-57.

Święcicka, Małgorzata, red. Miasto: przestrzeń zróżnicowana językowo, kulturowo i spolecznie. T. 1. Bydgoszcz, Wydawnictwo Uniwersytetu Kazimierza Wielkiego, 2006.

Wieczorkiewicz, Bronisław. Słownik gwary warszawskiej XIX wieku. Warszawa, PWN, 1966.

Witaszek-Samborska, Małgorzata, Anna Piotrowicz. Słownictwo gwary miejskiej Poznania w ujęciu tematycznym. Poznań, Wydawnictwo Nauka i Innowacje, 2018. 